\title{
The Role of Pre-Action Procedure in Settlement of Disputes in Transportation in Russia
}

\section{Viktor Shtykov}

\author{
Far Eastern Federal University, Russian Federation, Primorsky Territory, Vladivostok, Sukhanova str., 8
}

\author{
Doi:10.5901/mjss.2015.v6n5s3p93
}

\begin{abstract}
One of the peculiarities of the liability of the transport operator under the contract of transit of the cargo is in the presence in such a relationship of necessary pre-action procedure of disputes prior to recourse of the consignor or consignee to the court for protection of their violated rights. Compliance with the complaint procedure is carried out by requiring the transport operator the claims by the consignor or consignee. The general rule about the presence in relations of the transit of cargo of mandatory complaint procedure is established in the Civil code of the Russian Federation, at the same time, a more detailed regulation of the complaint procedure, namely the direction of the claim, the timing of consideration of the consequences of refusal in satisfaction of requirements shall is determined by transportation rules and codes, which leads to differentiated legal regulation of relations on the complaint procedure on the settlement of disputes in the sphere of cargo transportation. Despite the fact that the complaint procedure on the settlement of disputes plays a significant role in social relations, in the legislation of the Russian Federation there is no developed mechanism to encourage voluntary compliance, which leads to the fact that in the Russian practice complaint procedure is regarded rather as an additional encumbrance to the person whose rights were violated in the process of transit of cargo.
\end{abstract}

Keywords: pre-action procedure, complaint procedure, complaint.

\section{Introduction}

There is no doubt that the most common form of protection of violated rights is the submission of the application to the court. At the same time, this right may be restricted by law or by agreement at necessity of parties ' compliance with preaction procedure of the resolution of the dispute. This is stipulated in the legislation of the Russian Federation for disputes arising from the contract of transit of cargo. In accordance with section 1 of article 797 of the Civil Code of the Russian Federation (later the $\mathrm{CC}$ ) prior to the presentation to the transport operator of the claim arising from the transportation of cargo it is necessary to present the claim in the manner prescribed by the respective transport regulation or (the Civil Code of the RF).

According to statistics published on the website of the Judicial Department at the AF of the RF, courts of General jurisdiction in 2006 considered 7 million 564 thousand civil cases, and in 2010 these cases were considered for 12 million 914 thousand (Bratenkov S.I., 2011). The number of applications received in arbitration courts since their creation, increased almost 3 times (1992 - 480 applications, 2013 - 1371 279) (Analytical note to the statistical report on the work of arbitration courts in Russia in 2013, 2013). This suggests that in Russia do not work the mechanisms that encourage voluntary execution of obligations. About $30 \%$ of court decisions are made for the obvious cases where the defendants were required to satisfy such requirements at the pre-trial stage, without litigation at law. The reason is that a person who fails to fulfill the requirements of the law, in case of submission of the dispute for consideration has no risk. In extreme cases, the court will oblige him to perform various actions aimed at the fulfillment of the law. On a reasoned request to the fulfillment of the law, the citizen often hears the refusal without any arguments, and when he tries to explain his innocence, he is just send to the court. (Bratenkov S.I., 2011).

\section{Results and Discussions}

Russian legislation does not contain definitions of "pre-action", "complaint" or "complaint procedure". "Pre-action procedure of dispute" resolution" indicates the time resolution of the conflict that is, before applying to court. However, the presentation and consideration of complaints to the counterparty is a special procedure for the resolution of the dispute between the parties prior to its taking to court. In this sense, complaint procedure is a kind of pre-action order of settlement of disputes. It should be noted that in art. 125 of the Arbitration procedural code of the Russian Federation (hereinafter referred to as APC of the RF) is mentioned "on the complaint or other the pre-action procedure" (the 
Arbitration procedural code of the Russian Federation). Thus, the legislator in the APC of the RF actually equates these terms. From article 125 of the APC of the RF also follows that along with the complaint procedure there are other possible ways of pre-action settlement of legal conflicts. For example, an appeal to a higher official or body, if such dispute resolution procedure is permitted by law (e.g. by virtue of paragraph 3 of article 30.1 of the Code of the Russian Federation about administrative offences) (the Code of administrative offences of the RF); the direction to the taxpayer of a complaint for payment of the tax until the treatment of the corresponding complaint in court, etc. (Rakitina L.N. \& Markin A.V., 2005).

The APC provides the ability to resolve conflict not only through a settlement agreement, but also through other conciliation procedures. The article 148 of the APC says that the statement of complaint may be left without consideration, if was not complied with, established by law or contract, pre-action dispute resolution procedure. Such dispositions make it possible to provide in the contract the settlement of the dispute not only through negotiations, but also through recourse to mediation (Kudriashov A.A., 2009).

Thus, the pre-action procedure of settlement of disputes is broader than the complaint procedure, a concept that includes a variety of methods of protection of violated rights, including complaint procedures for resolving disputes.

As a specific feature of the contract of transit of cargo, mandatory complaint is provided by transport regulations and codes enforcement, independent, private, pre-action procedure for settling disputes about the law, the contents of which is the obligation of the presentation by the interested person immediately to the transport operator complaints for non-performance or improper performance of obligations under the transit of cargo, and also the duty of the transport operator to review and provide a timely response to the complaint (Nekhoroshikh A.M., 2004).

Contained in the legislation dispositions concerning the mandatory complaint procedure give the impression that this order is only prerequisite, anticipating the inevitable requests for judicial protection. The wording "prior to filing of suit ... is required to reclamation" indicates that prior to going to court, it is necessary to perform additional steps, meaning and sense of which the law does not give. This formulation combined with the negative consequences of non-compliance complaint procedure has resulted in the Russian practice the complaint is rather an additional "charge" of persons whose rights have been violated, and no effective means of protection (Rojkova M.A., 2008).

In order to solve this problem, S. I. Bratenkov proposes to extend to the citizens the possibility of pre-action settlement of disputes by setting the recovery of compensation for moral damages for unreasonable and a manifest denial of legitimate complaints, for failure to meet such requirements, for failure of consideration or for late referral to such requirements (Bratenkov S.I., 2011).

In our opinion, not the possibility of compensation of moral harm, but the possibility of fines for non-compliance on a voluntary basis of the requirements of the creditor should be set, as it is done in p. 6, article 13 of the RF Law "On protection of consumers' rights". In addition, the establishment of liability to a fine for dissatisfaction in voluntary proceeding of legal requirements gives the opportunity to apply for recovery of both citizens and organizations, while compensation for moral damages is only possible to the citizens. Thus, in transport regulations and codes a rule should be introduced where the following is stated: "In meeting by court the requirements of the consignor or any other person who in accordance with the transport regulations and codes has the right to make a complaint, the court charges from the transport operator for failure to voluntarily meet the requirements of the consignor or any other entity the penalty in the amount of fifty percent of the amount awarded by the court to the consignor or other person".

As rightly pointed out by M. Mednikova, "parties, often placing in the contract the need to comply with the complaint procedure, do not stipulate the procedure for submission and consideration of complaints and related other issues" (Mednikova M., 2006).

Taking into account given the above and the fact that the complaint procedure gives the opportunity to relieve the work of judges and to settle disputes between the parties in the pre-action procedure, it appears that the legislator would need to adopt a legal act that would regulate the procedure for filing complaints, its form, content, and also the sanction for failure to comply with the legal requirements set forth in the complaint.

With regard to the international practice of law-making, then, for example, the Convention on the contract for the international transit of cargos by road does not establish the necessity of filing a complaint (hereafter CMR) (Convention on the contract for international carriage of cargo, 1956). According to K. V. Kholopov, "according to a general rule having a complaint under the contract of transit is not mandatory, with the exception of complaints for damages due to violation of terms of delivery. This, in particular, comes from the contents of p. 1 of article 27 of the CMR. Failure to submit complain against a transport operator means that the entitled person, in a judicial or arbitration proceedings, would have to prove the fault of the transport operator, as before that there was no complaints to the transport operator from the direction of the authorized individual." (Kholopov K.V., 2010).

Russian legislation mandatorily establishes the obligation prior to the presentation to the transport operator of the 
complaint to show him the complaint. However, this provision only applies to relations arising from the contract of transit of cargos. Thus, it should be noted that the Code of inland water transport of the Russian Federation (further IT) departs from this principle, in p. 1 of article 161 states that prior to filing a lawsuit in connection with the transit of passengers, baggage, cargo to the transport operator necessary is to make a complaint to the transport operator.

When compliance with the complaint procedure there is a contradiction in p. 3 , article 30 of the Civil procedure code of the RF (hereinafter CPC RF) (claims against transport operator arising from contracts of transit, are presented to the court at the location of the transport operator, which in the prescribed manner was presented to him) and paragraph 2 of article 17 of the Law "On protection of consumer rights" (lawsuits about protection of consumers ' rights may be brought by the choice of the plaintiff: in the court at the location of the organization, in the court of the place of residence of the plaintiff, in the court of the place of conclusion or performance of the contract). According to M. V. Krotenkov, this conflict should be resolved in favour of weaknesses, that is, the consumer (Kratenkov M.V., 2010).

Thus, the complaint for non-performance or improper performance by the transport operator of its duties under the contract of transit of passengers and luggage is a right and not a duty of a citizen. When determining the jurisdiction of civil cases on disputes arising from contracts of transit of passengers and their luggage, the Supreme Court of the Russian Federation suggests to be guided by the Law "On protection of consumers' rights" and to file a suit on the coordinate jurisdiction and not, not exclusive (Erokhina T.P. , 2006).

This issue became the subject of the proceedings in the constitutional Court of the Russian Federation, where a complaint was addressed by a citizen of N., to admit p. 3, article 30 of the CPC of the Russian Federation misfitting articles 2, 18, 46 and 55 of the Constitution of the Russian Federation in connection with the fact that this norm, according to the applicant, limits his constitutional right to effective judicial protection, providing for consideration of disputes arising from contracts of transit of passengers only at the location of the transport operator, making it difficult to protect the rights of consumers in disputes with transport operators. In its determination, the constitutional Court of the RF pointed out, that part 3 of article 30 of the CPC of the Russian Federation in the system of existing legal regulation (i.e. in the absence of the mandatory presentation of a complaint to the transport operator) does not preclude the filing by a citizen of a complaint arising from the contract of transit of passengers or luggage by the rules of jurisdiction established for complaints for consumer protection (definition of the constitutional court, 2006).

Thus, firstly, it seems unreasonable to include in IT dispositions for mandatory submission of complaints in the transit of passengers and luggage, as there is no any of the specific features characteristic of the relations regulated by IT, compared with other transport regulations and codes, and therefore this disposition should be excluded. Secondly, based on the above given definition of the constitutional Court of the Russian Federation, it can be concluded that if the legislation establishes mandatory pre-action dispute settlement procedure, or if the plaintiff exercised his right to submit complaints to the transport operator, then it is necessary to follow the rule on exclusive jurisdiction, in other cases it is necessary to follow the Law "On protection of consumers' rights".

According to the article 123 of the RF Statute on Railway Transportation (hereinafter SRT) complaints may be filed within six months, and complaints for penalties and fines within forty-five days. Also, the transport operator may accept for consideration a complaint after established by article 123 of SRT terms, if it acknowledges the reason for missing the deadline of the complaint to be good. Therefore, if the transport operator admits the reason for missing the deadline for complaint disrespectful, it has the right not to consider such a complaint (Koval, A. V. 2006). Art. 126 of the Aviation Code of the Russian Federation (hereinafter AC) also sets the time period for presentation of complaints within six months.

At the same time, the Merchant Marine Code of the RF (hereinafter MMC) and IT do not establish a special term for complaint and in it they fully comply with the CC of the RF. Interesting is the procedure for establishing a special period for complaints in the transport regulations and codes. So, pursuant to the $1997 \mathrm{AC}$, the legislator has established a special deadline for complaint. In 1998 was adopted the Transport Regulation of the Railways (hereinafter TRR), the norms of which in respect of the complaint period was preserved in the current SRT of 2003. In 1999 and in 2001 were accepted accordingly IWTC and MMC. In connection with these interesting is which period for filing complaints established the legislator in the newest of all transport regulations and codes, namely in the regulation of motor transport and city ground-based electric transport of the Russian Federation (hereinafter RMT). According to part 6 of article 39 of the RMT complaints to the transport operators, charterer providers can be brought within the period of limitation of action.

However, whether on the basis of these norms can be concluded that beyond the complaint period the person who had not addressed with the complaint to the transport operator, will lose the right to judicial protection of his legitimate rights and interests? Obviously, no. According to P. V. Remishevski, "the right of a person to file a court complaint against the transport operator must not be due to the failure of the transport operator in satisfaction of the complaint, as provided by applicable law. Such conclusion is in contradiction with the basic principles of Russian law and contradictes to article 46 of the Constitution, under which everyone has the right to judicial protection of their rights" (Remishevski P.V., 2008). 
A conflict of norms of AC and SRT about the impossibility of judicial protection of their rights in connection with the filing of the complaint outside deadlines was eliminated by judicial practice (Braginski M.I. \& Vitryanski V.V., 2006). P. 28 of the Resolution of Plenum of the Supreme Arbitration court of the Russian Federation dated 12.11.1998 has determined that the filing by consignor or consignee complaints against the railway company outside the time limits established in article 139 of STR, provided that they comply with Transportation rules of procedure for submission of complaints is not ground for return of the statement of complaint (the resolution of the Plenum of the Supreme Arbitration court of the Russian Federation, 1998). Released in 06.10.2005 resolution of Plenum of SCC of the Russian Federation № 30 "About some questions of practice of application of the Federal law "Regulation of railway transport of the Russian Federation", cancels the order dated in 1998, but the position reflected in the resolution of the Plenum 1998 is retained (decree of the Plenum of the Supreme Arbitration court, 2005). The eighteenth arbitration appeal court went further in its decision and stated: "The plaintiff's complaint is presented in violation of the term under article $123 \mathrm{SRT}$, however, established on the complaint time limits was not preclusive, the complaint is sent within the statutory period of limitation with observance of the established order, in this connection the trial court reasonably considered the complaint on the merits based on the recognition complied with the complaint about the resolution of the present dispute (decision of the Eighteenth arbitration appeal court, 2009). A similar position is shared by the courts in case of the transportation by air. Thus, the arbitration court of Moscow in a decision dated 30.01.2006, 06.02.2006 notes that the complaint is returned to the defendant without consideration in connection with the omission of the term established by clause 1 of part 1 of article 126 of the CC. These circumstances do not indicate a failure by the plaintiff to the complaint procedure dispute resolution. In addition, admission of a six-month deadline for filing a complaint is not preclusive. This is evidenced by part 2 of article 126 of the $\mathrm{CC}$, in accordance with which the transport operator is entitled to proceed with the complaint after the deadline, if it acknowledges the reason for missing the deadline of the complaint. The abandonment of the complaint without consideration does not preclude the filing of a complaint, which follows directly from part 2 of article 128 of the CC. According to this norm of the period of limitation begins on the day after receipt by the consignor or consignee the answer about refusal in satisfaction of complaint. Since the abandonment of the complaint without consideration is actually a refusal in its satisfaction, the plaintiff has not lost the right to complaint (Decision of the Moscow Arbitration court, 30.01.2006, 06.02.2006).

As the consequences of non-compliance of the period of the complaint the Resolution of Plenum of the Supreme Arbitration court of the Russian Federation No. 30 States that when considering if a complaint is determined that the case has arisen due to breach by the plaintiff provided by the article 123 of SRT terms of a complaint against the transport operator, the court of arbitration in accordance with clause 1 of article 111 of the APC may be attributed to the plaintiff's legal costs (in full or in part) regardless of the outcome of the dispute.

Thus, as pointed out by N. N. Ostroumov, if air transportation comes within the purview of relevant international Convention, which defines complaint terms, the Russian court has no grounds for making a complaint to consideration if the complaint is stated with the violation of the Convention of complaint deadlines. According to paragraph 4 of article 31 of the Montreal Convention and article 26 of the Warsaw Convention "failing complaint within the times aforesaid, no action against the transport operator will not be accepted, except in the case of fraud on the latter" (Ostoumov N.N., 2006).

The case that the transport operator is obliged within thirty days from the date of receipt of the complaint to consider it and notify the consignor or the consignee about the approval or rejection of the complaint (article 128 WC, article MMC 407, article 163 IWTC, article 40 CMT, article 124 of SRT), is one of the few, when the article 797 of the CC of the RF fully correspond to the norms of the transport regulations and codes.

In the Resolution of the Plenum of the Supreme Arbitration court of the Russian Federation dated 06.10.2005 No. 30 is an explanation of the question of the date of satisfaction of the complaint. The court stated that the complaint shall be deemed satisfied provided that the actual transfer of a recognized transport operator of the amount or the restoration of records for his personal account. Otherwise, the plaintiff may apply to the court with the complaint to the transport operator on the recovery of the loss or recovery of record on the personal account. At the same time, recognition of the plaintiff's complaint and the failure to transfer of the recognized amount reflects the recognition by the debtor of the creditor's complaint, according to article 203 of the CC of the RF leads to interruption of the limitation period (Falkovich M.S., 2006).

In all transport regulations and codes, except MMC, stated that the response to the complaint shall be given in writing. Apparently, in this case we are dealing with another mistake of the legislator.

In addition, the content of the answer is satisfied only in certain normative statements (for example, article 124 of SRT). One should agree with D. A. Suvorov, who believes that the answer to the complaint must contain details similar to those described for complaint (Suvorov D.A., 2006). 


\section{Conclusion}

Thus, analysis of modern legal regulation of complaint procedure allows conclude that in the domestic legal system there are the following types of complaints:

1. Depending on compliance with peremptory norms guaranteeing the complaint procedure, the complaint may be mandatory (e.g. at the transit of cargos compliance with the complaint procedure is a prerequisite before filing a complaint in court) and not mandatory (for passengers and luggage compliance with the complaint procedure is not a prerequisite);

2. Depending on the period for filing a complaint, it can be simple, i.e. the law does not set a particular deadline for filing complaints and special, for example, under the contract of transit of cargos by railway or air carrier by the legislator is established a deadline for filing complaint within six months;

3. According of form there are the normative complaint, that is, its form is fixed by the legislator, for example, in section 1 of article $405 \mathrm{MMC}$ stated that the complaint is mandatory to be presented in writing and a traditional complaint, its form is not fixed by the legislator and the complaint is sent in the form established by the customs prevailing in the field of transportation.

In general it follows from the foregoing that the complaint procedure for resolving disputes is far from ideal. For example, it is the lack of a unified procedure for filing complaints to the transport operator and the absence of a complaint form, and unequal legal status of transport operators. In addition, the absence of real effective mechanism for the settlement of disputes leads to the fact that the complaint in the Russian practice is rather an additional obstacle to going to court, rather than the ability to promptly resolve the dispute outside the court.

Thus, the complaint procedure is not dependent on the type of transport and for its regulation it is necessary to apply general basics and principles.

\section{References}

Analytical note to the statistical report on the work of arbitration courts in the Russian Federation in 2013 http://www.arbitr.ru/_ upimg/BA56B64409E63370CC611FE1DCC99CB8_an_zap.pdf.

The arbitration procedural code of the Russian Federation dated 24.07.2002 № 95-FZ (as amended on 06.04.2015). Access from legalreference system ConsultantPlus.

Braginski, M.I. \& Vitryanski V.V. (2006). Contract law. Contracts of tranportation, towing, freight forwarding and other services in the field of transport (book 4). pp. 909

Bratenkov, S.I. (2011). Pre-trial settlement of disputes as a way to deal with the increasing workload of the judges.Russian justice. № 10. http://kraevoy.hbr.sudrf.ru/modules.php?name=press_dep\&op=3\&did=7.

Air Code of the Russian Federation. The law dated 19.03.1997 No. 60-FL (as amended on 14.10.2014). Access from legal-reference system ConsultantPlus.

Civil procedure code of the Russian Federation dated 14.11.2002 No. 138-FL (as amended on 01.05.2015). Access from legal-reference system ConsultantPlus.

Civil code of the Russian Federation. Part II (as amended on 06.04.2015).The act of 26.01.1996. Access from legal-reference system ConsultantPlus.

Erokhina, T.P. (2006). Some questions of application of the rules of exclusive territorial jurisdiction in civil proceedings. The Russian judge. № 2. pp. 25.

Koval, A.V. (2008) Legal regulation of transit of cargos by railway. Bulletin of the Moscow arbitration court. № 4. pp. 18-24.

The inland water transport code of the Russian Federation. The law dated 07.03.2001 No. 24-FL (as amended on 31.12.2014). Access from legal-reference system ConsultantPlus.

Code of the Russian Federation about administrative offences from 30.12.2001 № 195-FL (as amended on 08.06.2015). Access from legal-reference system ConsultantPlus.

Merchant shipping code of the Russian Federation. The act of 30.04.1999 No. 81-FL (as amended on 31.12.2014). Access from legalreference system ConsultantPlus.

Merchant shipping code of the Russian Federation. The act of 30.04.1999 No. 81-FL (as amended on 31.12.2014). Access of legalreference system ConsultantPlus.

Krotenko, M. V. (2010).Consumer protection services: a Handbook. Access from legal-reference system ConsultantPlus.

Kudryashov, A.A. Mediation in Russia. The notary. 2009. No. 2. pp. 43-44.

Mednikova, M. (2006). The finding of non-compliance with pre-action settlement of disputes by the arbitration court: application of procedural rules. Arbitration and civil process. No.11. pp. 24.

Nekhoroshokh, A.M. (2004). Complaint proceedings as the Institute prior to the settlement of disputes arising from the legal relationship on railway transport of cargos: author. dis. ... 12.00.15 / Nekhoroshikh A. M. http://www.dissercat.com/content/pretenzionnoeproizvodstvo-kak-institut-predvaritelnogo-dosudebnogo-uregulirovaniya-sporov-v. 
About some questions of practice of application of the Federal law Regulation of railway transport of the Russian Federation: the Decree of the Plenum of the Russian Federation No. 30, dated 06.10.2005. Access from legal-reference system ConsultantPlus.

About some questions of practice of application of the Federal law Regulation of railway transport of the Russian Federation: the Decree of the Plenum of the Russian Federation No. 30, dated 06.10.2005. Access from legal-reference system ConsultantPlus.

About some questions of practice of application of the Federal law Regulation of railway transport of the Russian Federation: the Decree of the Plenum of the Russian Federation No. 30, dated 06.10.2005. Access from legal-reference system ConsultantPlus.

Ostroumov, N.N. (2006). The air carrier's liability for baggage and cargo. The Statute, 2006. Access from legal-reference system ConsultantPlus.

The decision of the Eighteenth arbitration appeal court dated 05.11.2009 No. 18AP-9159/2009 in case No. A76-8967/2009. Access from legal-reference system ConsultantPlus.

Rakitina, L.N. \& Markin A.V. (2005) Complaint proceedings and "any other procedure of pre-action settlement of the dispute". Lawyer. № 8. pp. 12.

Remishevski, P.V. (2008) The problem of correlation filing period and the limitation period in the settlement of disputes arising from breach of contract of transit of cargos. Transport law. № 2. pp. 26.

The decision of the Arbitration court of Moscow dated 30.01.2006, 06.02.2006 case № A40-59695/05-32-474. Access from legalreference system ConsultantPlus.

Rojkova, M. The formatting rules for the submission and consideration of claims. Economy and law. 2008. No. 2 (Annex). Access from legal-reference system ConsultantPlus.

Suvorov, D.A. (2006) Claims, and other pretrial procedure in alternative forms of dispute resolution. The legal world. No. 7. pp. 34-40.

Transport regulation of the Railways.Fed. law dated 08.01.1998 No. 2-FL (repealed); (with am. from 06.07.2001). Access from legalreference system ConsultantPlus.

The regulation of road transport and urban land-electric transport. Fed. law of 08.11.2007 № 259-FL (as amended on 01.12.2014). Access from legal-reference system ConsultantPlus.

Regulation of railway transport of the Russian Federation. Fed. law of 08.11.2007 № 259-FL (as amended on 01.12.2014). Access from legal-reference system ConsultantPlus.

Falkovich, M.S. (2006) Complaints and lawsuits against the railway transport operator. Lawyer. № 31. pp. 87.

Kholopov, K.V. Private international transport law. Analysis of the norms of international and Russian transport law: textbook. The Statute, 2010. Access from legal-reference system ConsultantPlus. 